\title{
IPDA Filters in the Sense of Gaussian Mixture PHD Algorithm
}

\author{
Zvonko Radosavljević ${ }^{1)}$
}

\begin{abstract}
The Integrated Probabilistic Data Association (IPDA) type filters provide estimates of the underlying target probability of existence as well as they track state maintenance. For each scan, IPDA recursive calculates the probability of target existence in order to resolve the uncertainty. Likewise, Random Finite Set (RFS) is a method for single target and multi-target tracking. It provides a Bayesian recursion of multi-target distribution through the Finite Set calculus. Practical implementation of multi-target posterior recursion is too difficult. It was analytically proved that IPDA algorithm can be derived from the RFS based filter recursion under the linear Gaussian assumptions. Probability hypothesis density (PHD) filter is an alternative to this problem where only the first order moment of the complete multi-target posterior is propagated in time. In this article, IPDA and Gausian Mixtures PHD (GM PHD) filters in a single target tracking scenario are derived and compared. Simulations have demonstrated the superiority of IPDA filters in heavy clutters.
\end{abstract}

Key words: target designation, target tracking, radar tracking, Gauss-Markov process, IPDA filter, PHD filter, algorithm.

\section{Introduction}

$\mathrm{W}$ HEN tracking a single target in the presence of clutter, more than one measurement may be received at each scan after gating (measurement validation) process which eliminates measurements that fall outside a specified confidence region [1]. In general, track maintenance using false measurements can lead to serious filter divergence problem. Therefore, a data association technique is required to differentiate target originated measurement from clutter. In a typical target tracking scenario, measurements originate from sources other than the desired target itself. The possible sources may be terrain, clouds or even thermal sources present in the sensor surveillance region. These unwanted measurements are generally termed as "clutter" tracking involving a data association technique [2]. In essence, data association involves decision on which of the obtained measurements belong to target(s). It also hypothesizes the fact that no measurement may be target originated to clutter for the possibility of missed detection. The sequence of operations for a tracker in such case begins with the initiation phase where tracks are started based on the measurements of two successive scans. The IPDA, proposed by Mušicki, in $[1,3]$, has two options on choice of Markov chain models of target existence propagation. Markov Chain One, the default one, recognizes two possibilities: the target either does not exist, or it exists and is visible with a probability of detection. Markov Chain Two, denoted with IPDA as IPDA-M2, also recognizes the possibility of target existing but not being visible. The IPDA filters provide estimates of the underlying target probability of existence as well as they track state maintenance. These quantities are conveniently used as track quality measures and can be used for the track confirmation and termination.

However, in [3], it was analytically proved that IPDA algorithm can be derived from RFS based filter recursion under linear Gaussian assumptions [4,5,6]. A closed-form solution to the PHD recursion for linear Gaussian multi-target model was discovered $[7,8]$. This result was reported in [9, $10]$ together with the Gaussian mixture PHD filters for linear and mildly non-linear multi-target models. While more restrictive than SMC approaches, the Gaussian mixture implementations are much more efficient. Convergence results for the GM PHD filter were established in $[11,12]$. In [13] the Gaussian mixture PHD filter is extended to linear Jump Markov multi-target model for tracking maneuvering targets, while in [14] it is extended to produce track-valued estimates. This study compared IPDA single target tracking filter in the sense of the Gaussian Mixture PHD algorithm effectiveness.

Paper is organized as follows: after introductory considerations, Section 2 presents the mathematical problem formulation. In Section 3 we derive IPDA and GM PHD in the sense of Gaussian filtering. The common algorithms comparisons and simulation results are presented in Section 4 followed by concluding remarks in Section 5 .

\section{Problem formulation}

Any target tracking scenario is defined out of the probability of detection and clutter density. Again, the clutter density is depending on target dynamics and characteristics of sensor. Generally, clutter is defined by a number of selection measurement from the size of selection gate. At the beginning, the target state is to be considered. The scenario considers zero or at most one target. If the target exists, the target state $\mathrm{x}$ (which may consist of position, velocity or any other target dynamic parameter) follows the dynamic equation:

$$
x_{k}=F x_{k-1}+v_{k}
$$

\footnotetext{
1) Military Technical Institute (VTI), Ratka Resanovića 1, 11132 Belgrade, SERBIA

Correspondence to: Zvonko Radosavljević; e-mail: zvonko.radosavljevic@gmail.com
} 
where $F$ is the propagation matrix, and the process noise $v_{k}$ is a zero mean and white Gaussian sequence with covariance $Q_{k}$. Target measurement is modeled by the:

$$
y_{k}=H x_{k}+w_{k}
$$

where $H$ is the measurement matrix and the measurement noise $w_{k}$ is a zero mean and white Gaussian sequence with the covariance $R$, independent of $v_{k}$. A measurement of target $\tau$ is present in each scan with a probability of detection $P_{D}$. The sensor is also assumed to detect the target with certain and known probability of detection. At every time instant, the sensor receives clutter measurements. The number of clutter measurements received at any particular time is random and assumed to be governed by a Poisson distribution with known average. The received clutter measurements are distributed uniformly in the surveillance region. Clutter measurements follow the non-uniform Poisson distribution by clutter measurement density $\rho_{y}$.

\section{Derivation of IPDA and GMPHD}

Automatic track initiation in clutter will initialize true tracks which follow targets as well as false tracks which do not. We want to confirm true tracks and terminate false tracks. With on-line track quality measure, the IPDA type filters can be used for the track confirmation and termination, as well as the state estimation of tracks.

\section{Derivation of IPDA}

The IPDA proposed in [7] is derived based on PDAF [3] by introducing the concept of target existence. Two mutually exclusive and exhaustive events associated with the target existence were assumed, and modeled as a random variable $E_{k}$. $E_{k}$ - the target exists and is visible at time $k$,

$\bar{E}_{k}$ - the target does not exist at time k.

The occurrence of these two events is modeled as two states of the Markov Chain with transition probability matrix:

$$
\Pi=\left[\begin{array}{ll}
\pi_{11} & \pi_{12} \\
\pi_{21} & \pi_{22}
\end{array}\right]
$$

where

$$
\begin{gathered}
\pi_{i j} \cong P\left\{E_{k}=j \mid E_{k-1}=i\right\}, i, j=\{1,2\} \\
\pi_{11}+\pi_{12}=\pi_{21}+\pi_{22}=1
\end{gathered}
$$

is the transition probabilities for $\{i, j\}$ th entries and $P\{$. denotes probability. A priori probabilities of the track existence (Markov Chain One):

$$
\begin{aligned}
& P\left\{x_{k} \mid Z^{k-1}\right\}= \\
& =\pi_{11} P\left\{x_{k-1} \mid Z^{k-1}\right\}+\pi_{21}\left(1-P\left\{x_{k-1} \mid Z^{k-1}\right\}\right) \\
& 1-P\left\{x_{k} \mid Z^{k-1}\right\}= \\
& =\pi_{12} P\left\{x_{k-1} \mid Z^{k-1}\right\}+\pi_{22}\left(1-P\left\{x_{k-1} \mid Z^{k-1}\right\}\right)
\end{aligned}
$$

Applying definition of $P_{W}$ by the $P_{W}=\int_{V_{k}} f\left(z \mid Z^{k-1}\right) d V$, a priori PDF of a measurements from the target at scan $k$, given that it fell within the window is:

$$
p\left(z_{k, i} \mid x_{k, i}, Z^{k-1}\right)=\frac{1}{P_{W}} f\left(z_{k, i} \mid Z^{k-1}\right)
$$

- A priori PDF that no measurements originated from the target:

$$
P\left\{x_{k, 0} \mid Z^{k-1}\right\}=1-P_{D} P_{W} P\left\{x_{k} \mid Z^{k-1}\right\}
$$

- A priori PDF that the track exists and that no measurements originated from the target:

$$
P\left\{x_{k}, x_{k, 0} \mid Z^{k-1}\right\}=\left(1-P_{D} P_{W}\right) P\left\{x_{k} \mid Z^{k-1}\right\}
$$

- A priori PDF of measurements originated from the target, given that the track exists and that $m_{k}>0$ :

$$
P\left\{x_{k, i} \mid x_{k}, m_{k}, Z^{k-1}\right\}=P_{D} P_{W} / m_{k}
$$

The a priori probability density of measurements in the window, given that they are all false measurements:

$$
p\left(z_{k} \mid x_{k, 0}, m_{k}, Z^{k-1}\right)=\prod_{i=1}^{m_{k}} V_{k}^{-1}
$$

A priori probability density of measurements in the window, given that measurements $i$ is a target and all others are false measurements is:

$$
p\left(z_{k} \mid x_{k, i}, x_{k}, m_{k}, Z^{k-1}\right)=p\left(z_{k, i}, x_{k}, Z^{k-1}\right) \prod_{i=1}^{m_{k}} V_{k}^{-1}
$$

Now, the track existence at scan $k$ (event $x_{k}$ ) is composed of mutually exclusive event $x_{k}=\bigcup_{i=0}^{m_{k}} x_{k} x_{k, i}$ with

$$
P\left\{x_{k} \mid Z^{k}\right\}=P\left\{x_{k}, x_{k, 0} \mid Z^{k}\right\}+\sum_{i=1}^{m_{k}} P\left\{x_{k}, x_{k, i} \mid Z^{k}\right\}
$$

Using the theorem of total probability we have:

$$
P\left\{x_{k, 0} \mid Z^{k}\right\}+\sum_{i=1}^{m_{k}} P\left\{x_{k}, x_{k, i} \mid Z^{k}\right\}=1
$$

And applying the Bayes rule we get:

$$
\begin{gathered}
P\left\{x_{k, 0} \mid Z^{k}\right\}=P\left\{x_{k, 0} \mid z_{k}, Z^{k-1}\right\}= \\
=c_{k}^{-1} p\left(z_{k} \mid x_{k, 0}, Z^{k-1}, m_{k}\right) P\left\{m_{k} \mid x_{k, 0}, Z^{k-1}\right\} P\left\{x_{k}, x_{k, 0} \mid Z^{k-1}\right\}= \\
=\frac{\hat{m}_{k}\left(1-P_{D} P_{W} P\left\{x_{k} \mid Z^{k-1}\right\}\right)}{C_{k} V_{k}} \\
P\left\{x_{k} \cdot x_{k, 0} \mid Z^{k}\right\}=P\left\{x_{k}, x_{k, 0} \mid z_{k}, Z^{k-1}\right\}= \\
=c_{k}^{-1} p\left(z_{k} \mid x_{k, 0}, Z^{k-1}, m_{k}\right) \cdot \\
\cdot P\left\{m_{k} \mid x_{k, 0}, Z^{k-1}\right\} P\left\{x_{k}, x_{k, 0} \mid Z^{k-1}\right\}= \\
=\frac{\hat{m}_{k}\left(1-P_{D} P_{W} P\left\{x_{k} \mid Z^{k-1}\right\}\right)}{C_{k} V_{k}}
\end{gathered}
$$




$$
\begin{aligned}
& P\left\{x_{k}, x_{k, i} \mid Z^{k}\right\}=P\left\{x_{k}, x_{k, i} \mid z_{k}, Z^{k-1}\right\}= \\
& =c_{k}^{-1} p\left(z_{k} \mid m_{k}, x_{k, i}, x_{k}, Z^{k-1}\right) \cdot \\
& \cdot P\left\{m_{k} \mid x_{k, i}, x_{k}, Z^{k-1}\right\} P\left\{x_{k, i} \mid x_{k}, Z^{k-1}\right\}= \\
& =\frac{\left.p\left(z_{k, i} \mid x_{k, i}, Z^{k-1}\right) P_{D} P_{W} P\left\{x_{k} \mid Z^{k-1}\right\}\right)}{C_{k}}
\end{aligned}
$$

In case of no measurements in the window, $m_{k}=0$ the probability of track existence can be calculated by the derivation:

$$
\begin{aligned}
& P\left\{x_{k} \mid Z^{k}\right\}=P\left\{x_{k} \mid z_{k}, Z^{k-1}\right\}= \\
& =\frac{P\left\{z_{k} \mid x_{k}, Z^{k-1}\right\} P\left\{x_{k} \mid Z^{k-1}\right\}}{P\left\{z_{k} \mid Z^{k-1}\right\}}= \\
& =\frac{P\left\{x_{k}, x_{k, 0} \mid Z^{k-1}\right\}}{P\left\{x_{k, 0} \mid Z^{k-1}\right\}}=\frac{\left(1-P_{D} P_{W}\right) P\left\{x_{k} \mid Z^{k-1}\right\}}{1-P_{D} P_{W} P\left\{x_{k} \mid Z^{k-1}\right\}}
\end{aligned}
$$

Data association probabilities are calculated as below:

$$
\begin{aligned}
& \beta_{k, i}= \\
& =P\left\{x_{k, i} \mid x_{k}, Z^{k}\right\} \frac{P\left\{x_{k}, x_{k, i} \mid Z^{k-1}\right\}}{P\left\{x_{k} \mid Z^{k-1}\right\}}, i=0,1, \ldots, m_{k}
\end{aligned}
$$

The target state estimate conditioned on the target existence and its associated covariance is obtained as:

$$
\begin{gathered}
\hat{x}_{k \mid k}=\sum_{i=0}^{m_{k}} \beta_{i, k} \hat{x}_{k \mid k}^{i} \\
P_{k \mid k}=\sum_{i=0}^{m_{k}} \beta_{i, k}\left(P_{k \mid k}^{i}+\hat{x}_{k \mid k}^{i} \hat{x}_{k \mid k}^{i}\right)-\hat{x}_{k \mid k}^{i} \hat{x}_{k \mid k}^{i T}
\end{gathered}
$$

where $\hat{x}_{k \mid k}^{0}=\hat{x}_{k \mid k-1}, P_{k \mid k}^{0}=\left(1+q_{0} K H\right) P_{k \mid k-1}$ is the corrected predicted error covariance, $K$ is the Kalman gain, $q_{0}$ is known constant.

\section{Derivation on GM PHD}

Instead the IPDA, Gaussian model for individual targets includes certain assumptions on the birth, death and detection of targets. The GM PHD recursion has also been derived the state dependent target survival and detection probabilities. The GM PHD recursion propagates the intensity function that is approximated with a Gaussian mixture by analytically propagating the weights, means and covariances of the Gaussian mixture terms. The updated intensity function is also a Gaussian mixture. In case there is one sensor, this method can be employed. Hereafter, we outline the GMPHD filter with the assumption there are no spawning objects. In case there are spawning objects, the prediction equation is modified by adding Gaussian components representing for spawning objects [4].

Schematic diagram of GM PHD implementation is given in Fig.1.

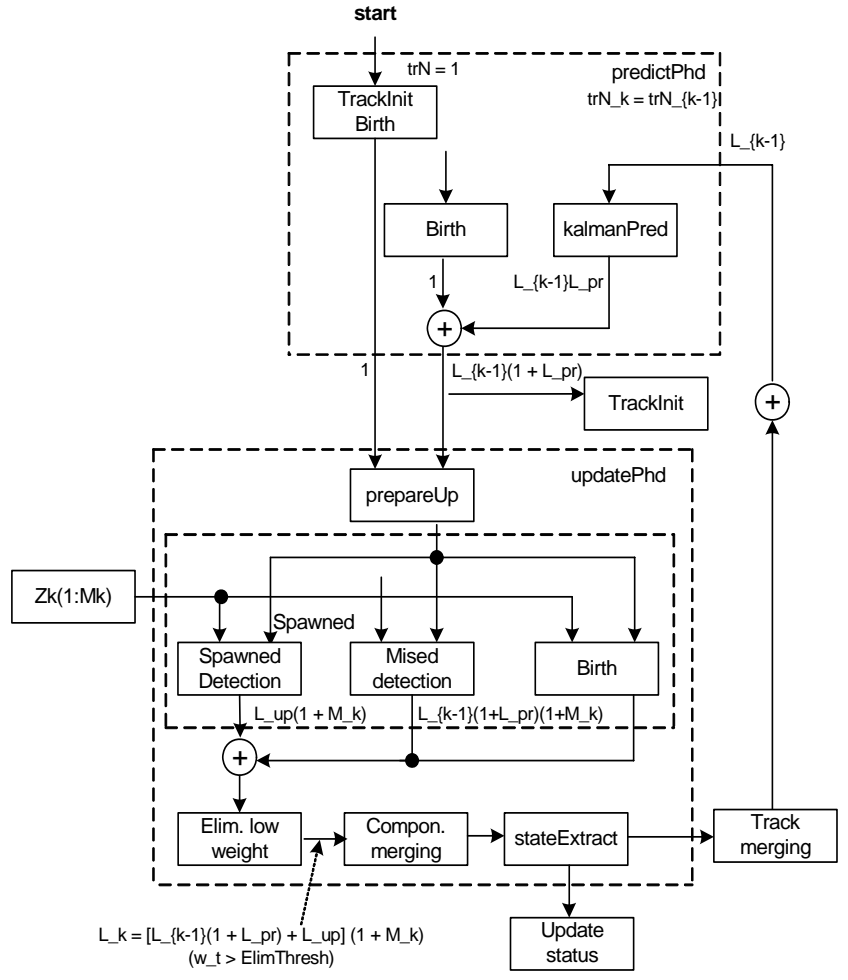

Figure 1. Schematic diagram of GM PHD implementation

Prediction step: Under the assumptions that target follow a linear Gaussian dynamical model, the survival and detection probabilities are constant, the intensities of the birth and spawned targets are equal to zero, and that the posterior intensity at time k-1 is a Gaussian mixture of the form

$$
L_{k-1}\left(X^{k}\right)=\sum_{i=1}^{J_{k-1}} w_{k-1}^{i} N\left[X^{k} ; m_{k-1}^{i}, P_{k-1}^{i}\right]
$$

Then the predicted intensity to time $k$ is a Gaussian mixture, and is given:

$$
L_{k \mid k-1}(x)=L_{S, k \mid k-1}(x)
$$

where $L_{S k \mid k-1}(x)$ is the PHD of existing targets and determined from the linear Gaussian model by the:

$$
L_{S k \mid k-1}(x)=p_{S, k} \sum_{j=1}^{J(k-1)} w_{k-1}^{j} N\left[x ; m_{S k \mid k-1}^{j}, P_{S, k \mid k-1}^{j}\right]
$$

where

$$
\begin{gathered}
m_{S k \mid k-1}^{j}=F(k-1) m_{k-1}^{j} \\
P_{S, k \mid k-1}^{j}=Q_{k-1}+F_{k-1} P_{k-1}^{j} F_{k-1}^{T}
\end{gathered}
$$

Update step: Under the above assumptions, and if the predicted intensity to time $k$ is a Gaussian mixture:

$$
L_{k \mid k-1}(x)=\sum_{i=1}^{J_{k \mid k-1}} w_{k \mid k-1}^{i} N\left[x ; m_{k \mid k-1}^{i}, P_{k \mid k-1}^{i}\right]
$$

then the posterior intensity at time $k$ is also a Gaussian mixture and is given by

$$
L_{k}(x)=\left(1-p_{D, k}\right) L_{k \mid k-1}(x)+\sum_{y \in Y} L_{D k}(x ; z)
$$


where

$$
\begin{gathered}
L_{D k}(x ; z)=\sum_{i=1}^{J_{k \mid k-1}} w^{i}(z) N\left[x ; m_{k \mid k}^{i}(z), P_{k \mid k}^{i}\right] \\
w^{j}{ }_{k}(z)=\frac{p_{D k} w_{k \mid k-1}^{i} q_{k}^{(j)}(z)}{\kappa_{k}(y)+p_{D k} \sum_{l=1}^{J_{k \mid k-1}} w_{k \mid k-1}^{l} q_{k}^{(j)}(z)} \\
q_{k}^{(j)}(z)=N\left[z ; H_{k}, m_{k \mid k-1}^{l}, R_{k}+H_{k} P_{k \mid k-1}^{l} H_{k}^{T}\right]
\end{gathered}
$$

and the mean and covariance are updated with the Kalman filter update equations,

$$
\begin{gathered}
m_{k \mid k,}^{j}(z)=m_{k \mid k-1,}^{j}(z)+K_{k}{ }^{j}\left[z-H_{k} m_{k \mid k-1}^{j}(z)\right] \\
P_{k \mid k}^{j}=\left[I-K^{j}{ }_{k} H_{k}\right] P^{j}{ }_{k \mid k-1} \\
K^{j}{ }_{k}=P^{j}{ }_{k \mid k-1} H^{T}{ }_{k}\left[H_{k} P^{j}{ }_{k \mid k-1} H^{T}{ }_{k}+R_{k}\right]^{-1}
\end{gathered}
$$

Given that the initial intensity function $L_{0}$ at time step $k=0$ is a known Gaussian mixture, the posterior intensity function at time step $k>0$ is also a Gaussian mixture from which the estimates of individual target states need to be extracted via peak extractions.

\section{Results of Simulations}

Consider a target motion scenario (Fig.2) with nonmaneuvering constant velocity $(\mathrm{CV})$ flight mode, similar to the previous work [15]. Speed is constant with $311 \mathrm{~m} / \mathrm{s}$. The sampling period of radar sensor is $T=1 \mathrm{~s}$. Duration of the scenario is 50 scans.

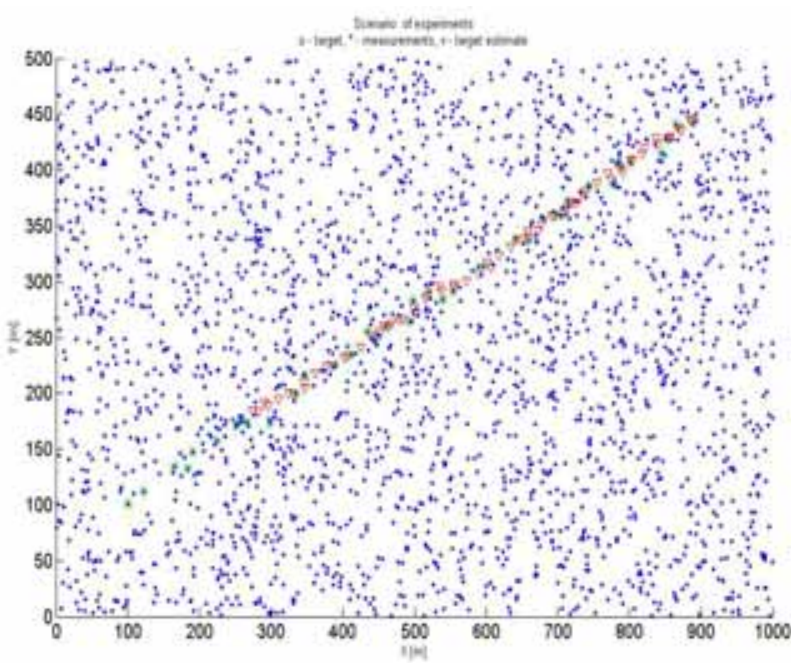

Figure.2 Simulations scenario: measurements and target

The target moves in the region $x=[0 ; 1000], y=[0 ; 500]$ and can appear or disappear in the scene at any time. The target states consist of positions and velocities and move according to the linear and Gaussian target dynamics.

The system input is modeled as follows: vector state $x_{i}(k)=\left[\begin{array}{llll}x & \dot{x} & y & \dot{y}\end{array}\right]^{T}$ where $x, y$ are the Cartesian coordinates of the target position, $\dot{x}, \dot{y}$ are the appropriate velocities. Initial target state is given by $\mathbf{x}_{1}(0)=[100 ; 16.0 ; 100 ; 7.0]^{T}$.
Transition matrix and process noise matrix are given by:

$$
\mathbf{F}_{1}=\left[\begin{array}{llll}
1 & T & 0 & 0 \\
0 & 1 & 0 & 0 \\
0 & 0 & 1 & T \\
0 & 0 & 0 & 1
\end{array}\right] \mathbf{Q}(k)=q\left[\begin{array}{cccc}
T^{3} / 3 & T^{2} / 2 & 0 & 0 \\
T^{2} / 2 & T & 0 & 0 \\
0 & 0 & T^{3} / 3 & T^{2} / 2 \\
0 & 0 & T^{2} / 2 & T
\end{array}\right]
$$

respectively, where $q=0.0052$ is a maneuver coefficient. The Integrated Track Splitting (ITS) simulation process is governed by a Markov Chain one. The calculations are based on Monte Carlo (MC) simulations using $N_{M C}=100$ realizations. During the one cycle of simulations, we have equal number of confirmed false tracks. This is achieved by adjusting initial probability of detection, while the confirmation threshold is the same and equal 0.95 . In these circumstances, the number of false confirmed tracks is 20 , overall the experiment for a period of 100 Monte Carlo simulations.

The measurement noise is also independent of the process noise. The probability of detection is assumed almost unity. Examined probability of detections is $\mathrm{P}_{D}=0.7$. Clutter is uniformly distributed over the observation space with an average rate of 50 points per scan. The results of experiments are given via three comparative parameters: number of confirmed true tracks, number of confirmed false tracks and root mean square error position (Fig.3-5, respectively). Diagram of confirmed true tracks over all simulations (Fig.3) shows better performance of IPDA instead of GM PHD filters, in heavy clutter environments.

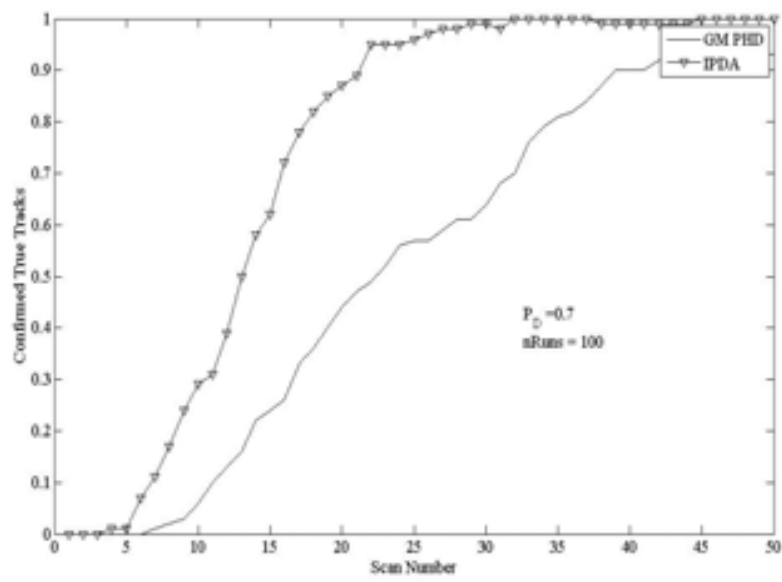

Figure 3. Diagram of confirmed true tracks over simulation

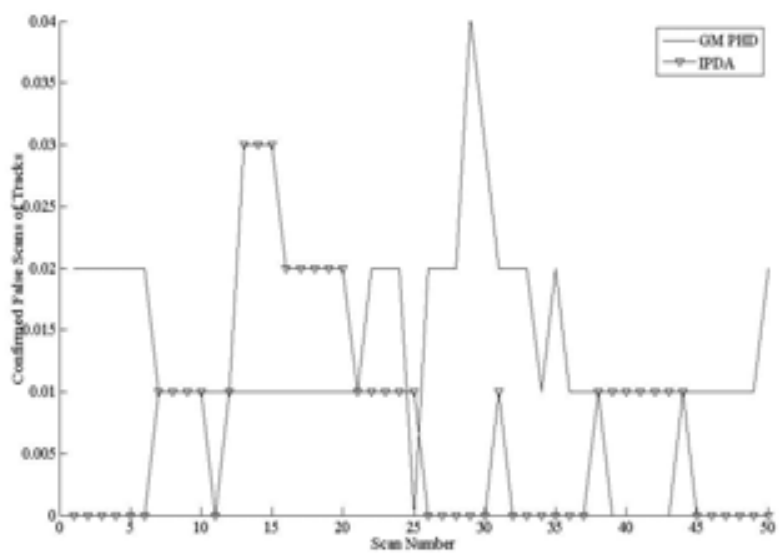

Figure 4. Diagram of confirmed false tracks over simulation 


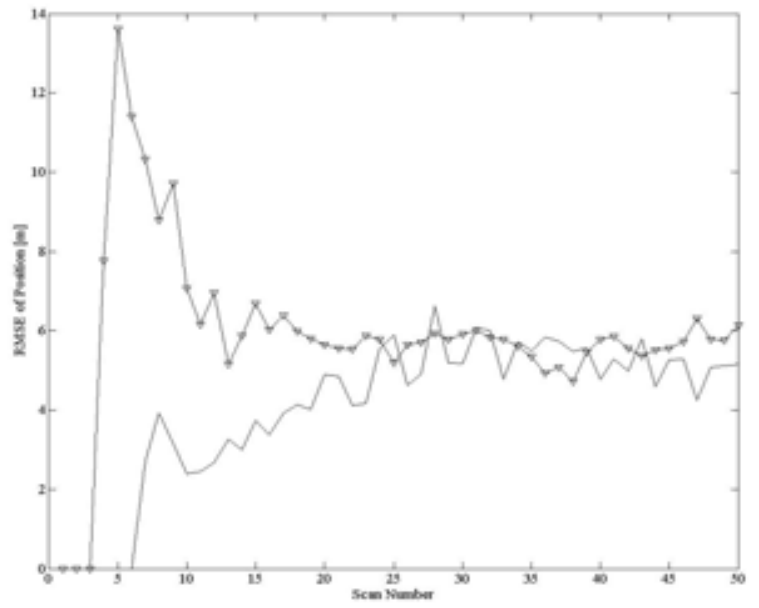

Figure 5. Comparative diagram of root mean square error of position

\section{Conclusions}

The paper has compared the two GM-based target tracking algorithms: IPDA and GM PHD. The IPDA is the target existence and Bayes-based solution, newly represented here as a target density filter. The GM PHD is an approximation of the Bayes random set solution and the target density filter is its natural form. The modeling assumptions are translated into requirements for mutual exclusiveness of the same-track components and mutual exclusiveness of the feasible joint events. The GM PHD does not follow these requirements which indicate a future work to improve the GM PHD performance. The IPDA paradigm, on the other hand, may benefit from the elegant GM PHD birth and track splitting processes. Results of simulations with single target tracking scenario showed better track measure performance than GM PHD algorithms. In future, we should try multi target tracking experiments.

\section{Acknowledgement}

The author would like to thank to deceased professor Darko Mušicki, (Hanyang University, An San, Republic of South Korea), who has began this research.

\section{Reference}

[1] MUŠICKI,D., EVANS,R., STANKOVIĆ,S.: Integrated Probabilistic Data Association, IEEE Transaction of Automatic Control, June 1994, 39, pp.1237-1241.

[2] MUŠICKI,D., EVANS,R.: Joint integrated probabilistic data association -JIPDA, IEEE Trans. Aerosp. Electron. Syst., 2004, 40, (3), pp. 1093-1099

[3] CHALLA,S., VO,B.N., WANG,X.: Bayesian approaches to track existence - random sets and IPDA, Fifth Int. Conf. on Information Fusion, Fusion 2002, Annapolis, USA, July 2002.

[4] CHAKRAVORTY,R., CHALLA,S.: Multitarget tracking algorithmjoint IPDA and Gaussian mixture PHD filter, 12th Int. Conf. on Information Fusion, Fusion 2009, Seattle, USA, July 2009, pp.316-323

[5] SONG,T.L., MUŠICKI,D., KIM,D.S., RADOSAVLJEVIĆ,Z.: Gaussian mixtures in multi-target tracking: a look at Gaussian mixture probability hypothesis density and integrated track splitting, IET proceedings on Radar Sonar and Navigation, June 2012, Vol.6, No.5, pp.359-364.

[6] RADOSAVLJEVIĆ,Z., MUŠICKI,D., KOVAČEVIĆ,B., KIM,W.C., SONG,T.L.: Integrated particle filter for target tracking in clutter, IET proceedings on Radar Sonar and Navigation, DOI: 10.1049/ietrsn.2014.0341, Print ISSN 1751-8784, May 2015.

[7] MAHLER,R.: Random-set approach to data fusion, 29 July 1994 SPIE Vol.2234.

[8] GOUTSIAS,J., MAHLER,R., NGUYEN,H. (eds.): Random Sets Theory and Applications, Springer-Verlag New York, 1997.

[9] GOODMAN,I., MAHLER,R., NGUYEN,H.: Mathematics of Data Fusion, Kluwer Academic Publishers, 1997.

[10] VO,B.N., MA,W.K.: A closed-form solution for the probability hypothesis density filter, Proc. Information Fusion, 8th International Conference, July 2005, Vol.2, pp.25-28.

[11] VO,B.N., MA,W.K.: The Gaussian mixture Probability Hypothesis Density filter, IEEE Trans. Signal Processing, IEEE Trans. Signal Processing, 2006, Vol.54, No.11, pp.4091-4104.

[12] CLARK,D.E., VO,B.N.: Convergence analysis of the Gaussian mixture Probability Hypothesis Density filter, IEEE Trans. Signal Processing, 2007, Vol.55, No.4, pp.1204-1212.

[13] PASHA,A., VO,B.N., TUAN,H.D., MA,W.K.: Closed-form solution to the PHD recursion for jump Markov linear models, Proc. 9th Annual Conf. Information Fusion, Florence, Italy, 2006.

[14] CLARK,D.E., PANTA,K., VO,B.N.: The Gaussian mixture PHD filter Multiple Target Tracker, Proc. 9th Annual Conf. Information Fusion, Florence, Italy, 2006.

[15] RADOSAVLJEVIĆ,Z., SONG,T.L., KOVAČEVIĆ,B.: Linear MultiTarget IPF Algorithm for Automatic Tracking, Scientific Technical Review, ISSN 1820-0206, 2016, Vol.66, No.1, pp.3-10.

\title{
IPDA filteri u smislu Gausovog mešovitog proizvoda PHD algoritma
}

\begin{abstract}
Integrisani filter pridruživanja podataka po verovatnoćama (IPDA) daje procene verovatnoća postojanja cilja, potrebne za održavanje stanja traga. U svakom okretaju antene radara, IPDA rekurzivno izračunava verovatnoću postojanja cilja u svrhu rešavanja neizvesnosti oko postojanja cilja. Na sličan način, metoda slučajnog konačnog skupa (RFS) namenjena je za praćenje jednog ili više ciljeva. Koristeći Bajesova pravila, rekurzivno izračunava distribuciju konačnog skupa više ciljeva. Praktična primena ovog sistema praćenja je veoma teška. Analitički je dokazano da se IPDA algoritam može uporediti sa rekurzijom slučajnog konačnog filtra (RFS) jer se zasniva na linearnim Gausovih pretpostavkama. Algoritam gustine verovatnoće hipoteza (PHD) je alternativa ovom problemu gde se koristi prvi momenat posteriorne verovanoće cilja koja propagira kroz vremenske odbirke prilikom okretaja antene. U ovom radu, izvedeni su i upoređeni algoritmi IPDA i Gausov mešaviti proizvod PHD filtra u linearnom scenariju praćenja jednog cilja. Simulacije su pokazale superiornosti praćenja cilja IPDA algoritmom u uslovima gustog klatera.
\end{abstract}




\title{
Фильтры IPAD в роли смешанного фильтра гаусса PHD алгоритма
}

\begin{abstract}
Встроенный фильтр вероятностей типа Integrated Probabilistic Data Association (IPDA) предоставляет оценки вероятностей существования целей, необходимые для поддержания статуса метки. В каждом обороте антенны радара, IPDA рекурсивно вычисляет вероятность существования мишени с целью разрешения неопределённости относительно существования мишени. Аналогично, метод случайного конечного множества (Random Finite Set - RFS) предназначен для отслеживания одной или нескольких целей. Использование правила Байесова рекурсивно вычисляет распределение конечного набора больше целей. Практическая реализация этой системы мониторинга очень сложная. Мы аналитически доказали, что алгоритм IPDA может быть получен из рекурсии случайного фильтра тонкой очистки (RFS), так как он основан на линейных предположениях Гаусса. Алгоритм плотности гипотетической вероятности (PHD) является альтернативой к этой проблеме, где вовремя используется и распространяется только первый момент задней вероятности целей, распространяющихся через временные выборы при обороте антенны. В данной статье получены и сравниваются алгоритмы IPDA и смешанный фильтр Гаусса PHD в линейном сценарии отслеживания одной цели. Эксперименты показали превосходство отслеживания цели IPDA алгоритмом в условиях плотных и тяжёлых помех.
\end{abstract}

Ключевые слова: обнаружение цели, слежение за целью, отслеживание РЛС, процесс Гаусса-Маркова, IPAD фильтр, PHD фильтр, алгоритм

\section{Les filtres IPDA dans le sens de l'algorithme mixte de Gauss}

Le filtre intégré de l'association des données selon les probabilités ( IPDA) fournit les estimations des probabilités sur l'existence de cible nécessaires pour maintenir l'état de trace. Dans chaque tour de l'antenne de radar IPDA calcule récursivement la probabilité de l'existence de cible dans le but de résoudre l'incertitude de l'existence de cible. De même la méthode de l'ensemble fini aléatoire (RFS) est destinée pour le suivi d'une ou plusieurs cibles. En utilisant les principes de Bayesian elle calcule récursivement la distribution de l'ensemble final pour plusieurs cibles. L'application pratique de ce système de suivi est très difficile. On a prouvé analytiquement que l'algorithme IPDA peut être dérivé de la récurrence du filtre aléatoire fini (RFS) car il est basé sur les assomptions linéaires de Gauss. L'algorithme de la densité de probabilité des hypothèses $(\mathrm{PHD})$ est l'alternative à ce problème où on utilise le premier moment de la probabilité postérieure de la cible qui propage à travers les choix temporels pendant les touts de l'antenne. Dans ce papier on a dérivé et comparé les algorithmes IPDA et le produit mixte du filtre PHD de Gauss dans le scénario du suivi de cible. Les essais ont démontré les supériorités de suivi de cible par l'algorithme IPDA dans les conditions du dense désordre.

Mots clés: détection de cible,suivi de cible,suivi par radar, processus de Gauss Markov, filtre IPDA, Filtre PHD, algorithme. 